tem made it easier for ministries to create independent research institutes rather than bureaux directly attached to industry. Inevitably this created a rift between research and production in the different branches of industry. The heavy dependence on salaries from academic qualifications made scientists spend too much of their productive lives in obtaining degrees, not practical results. Eventually science lost its attractiveness for young talent - nearly all prominent Soviet scientists are now well over the age of 50 . It was not, therefore, surprising that the participants at the NATO symposium failed to find either perestroika or revolution in Soviet science. Only a gradual evolution over the next decade was predicted which may make research and development "more responsive to the needs of the country".

This was certainly Gorbachev's own conclusion, after three years of waiting for results, and more radical measures have recently been introduced by the Central Committee. From 1988 all the ministerial research networks (which take about 60 per cent of the Soviet research and development budget, the rest being consumed by the academies and higher-education establishments) have been transferred to 'self-financing' schemes which will enable them to earn money from contracts within industry, not from the state budget. Undertaking business trips to socialist countries has been made simpler; travel to Western countries is also under review, and might be made more flexible. Retirement at 70, even for academicians, is now mandatory. And the problems of young scientists, who have been awarded a $20-30$ per cent increase in salary (which had dropped to half that of an average industrial wage during the 1970s), have also been tackled. These and other reforms are all designed to bring about an "acceleration" in the development of science and technology.

Far reaching as such reforms might seem, they remain part of an attempt to prove the benefits of 'socialist' science and to make it a showpiece of the advantages of the Soviet political and economic system. Soviet science has great potential, which is apparent from its excellence in many theoretical fields. But all the current reorganization is essentially bureaucratic and carried out from above. The Soviet leadership still refuses to acknowledge the global characer of scientific and technological development. The best way for the Soviet Union to benefit from Western success in science and technology is more likely to be in integration with it, not in an attempt to generate its own separate revolution.

Zhores A. Medvedev is at the National Institute for Medical Research, Mill Hill, London NW7 IAA, UK. His most recent book is Soviet Agriculture, which was published late last year by W.W. Norton.

\section{Transformation in biochemistry}

\section{David Saggerson}

Biochemistry, 3rd edn. By Lubert Stryer. W.H. Freeman: 1988. Pp.1,089. Hbk $\$ 47.95, £ 39.95 ; p b k £ 24.95$.

IT IS seven years since the second edition of this enormously popular book appeared, and the need for overhaul and updating had clearly become pressing. Remaining as the sole author, Lubert Stryer has performed a prodigious feat to produce a worthy successor. To those for whom the second edition had become an old friend, much of the new edition will be familiar. Many of the excellent illustrations are retained, together with a substantial portion of the text. For all that, it is clear that a major transformation has been wrought.

With 1,089 pages of slightly larger size, the increase in information content is about 40 per cent over that in the second edition. The book is now divided into six rather than five parts as a result of the creation of a new Part I entitled "The Molecular Design of Life". This describes the basics of protein and nucleic-acid structure, and outlines the flow of genetic information, gene analysis and DNA cloning methods. The new section therefore reflects the growing interrelationships between biochemistry and molecular biology by showing, in particular, how techniques of protein and nucleic-acid chemistry have become mutually reinforcing. The requirement for an early introduction to some molecular biology becomes obvious when, in later chapters, frequent reference is made to RNA splicing and to the correspondence of exons with functional units within proteins.

The sequence of the following five parts ("Protein Conformation, Dynamics and Function"; "Generation and Storage of Metabolic Energy"; "Biosynthesis of Macromolecular Precursors"; "Genetic Information"; and "Molecular Physiology") is the same as before and remains logical. My only quibble is that photosynthesis arrives only in Chapter 22 and is therefore separated by almost 100 pages from Chapter 17 on respiration and oxidative phosphorylation. I would have thought there was a compelling case for these two topics to be placed side by side.

Striking full colour illustrations continue to be a major feature throughout and colour computer graphics have now also been employed to illustrate proteins and nucleic acids in three dimensions. As before, each chapter is followed by a list of selected reading and a set of problems. The suggested readings run up to 1986 and in many cases go considerably beyond the subject matter covered in the text. I challenged the index on numerous occasions and found it to be thorough and complete.

What individual topics are particularly new and timely, or have been thoroughly reworked in this edition? The following list is not exhaustive, but one should particularly mention blotting techniques; solid-phase methods for peptide and oligonucleotide synthesis; monoclonal antibodies; site-specific mutagenesis; insertion and expression of genes in plant and animal cells; reconstitution of membrane systems; use of nuclear magnetic resonance in metabolic studies; the chemiosmotic hypothesis (a very readable account); protein targeting to specific cellular locations; viruses and oncogenes; and transmembrane signalling processes.

A particular strength of the book is in

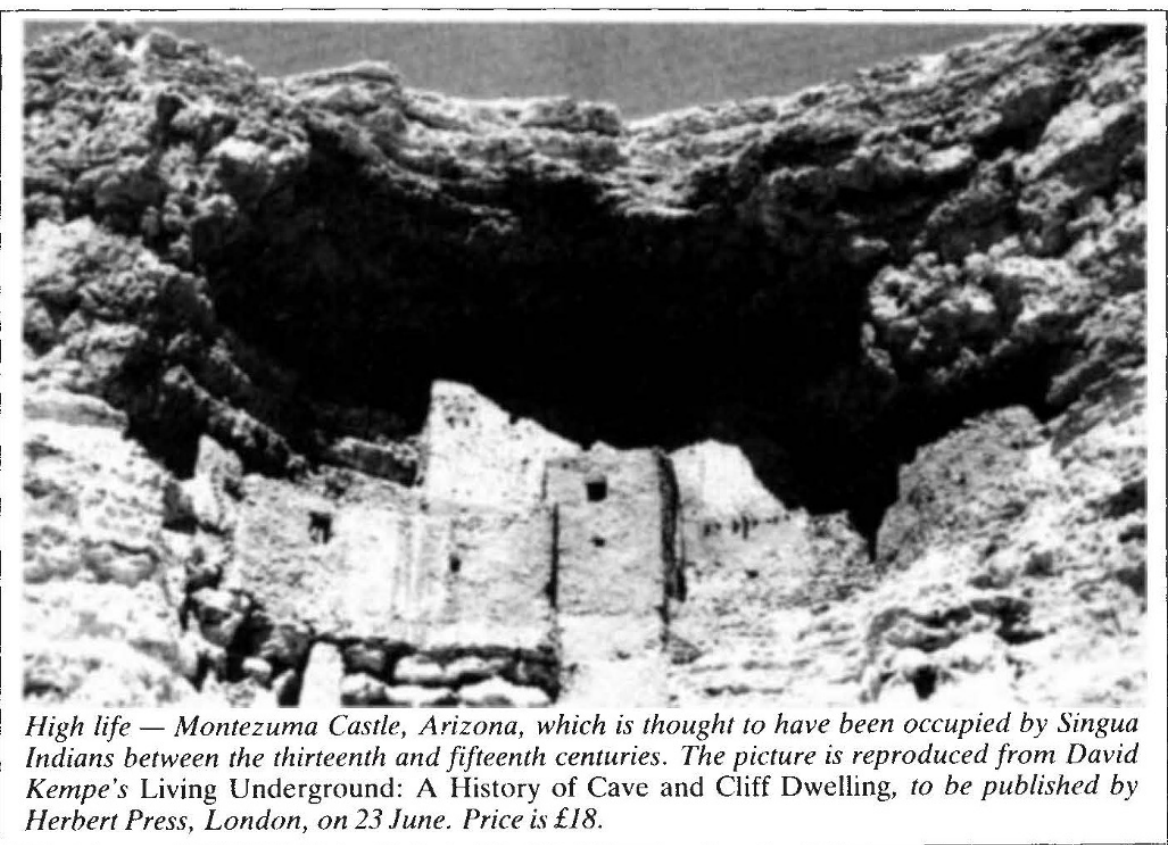

